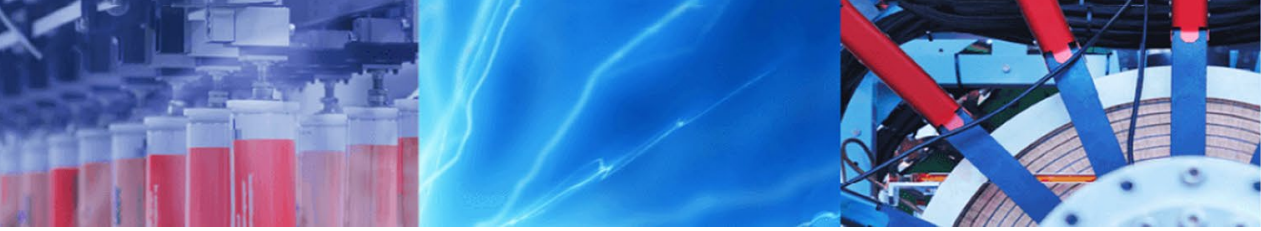

Research Article

\title{
Development and standardization of quality control parameters of different parts of Trianthema portulacastrum $\mathrm{L}$.
}

\author{
Anand Prakash ${ }^{1} \cdot$ Pracheta Janmeda $^{1} \cdot$ Purnima Pathak ${ }^{1} \cdot$ Sneha Bhatt ${ }^{1,2} \cdot$ Vinay Sharma $^{3}$
}

() Springer Nature Switzerland AG 2019

\begin{abstract}
The present study about Trianthema portulacastrum (Linn.), family Aizoaceae, is an effort to evaluate physicochemical parameters, phytochemical screening, pharmacognostic properties of stem, root, leaf and seed and preparedness of different extracts by solvent system of wide-range polarity. Physicochemical analysis includes loss on dryness, total ash value, water-soluble ash value, acid-insoluble ash value, $\mathrm{pH}$ analysis, fluorescence study and extractive values in different solvent systems. All the parts of the plant showed loss on dryness in the range of $2 \pm 0.69$ to $7 \pm 0.73$. Foreign organic matters recorded in different parts of plant were in the range of $0.8 \pm 0.045$ to $2.0 \pm 0.081$. The total ash values were determined from $9.59 \pm 1.87$ to $15.54 \pm 1.21 \%(\mathrm{w} / \mathrm{w})$. The water-soluble ash values were from $7.5 \pm 1.10$ to $9.38 \pm 1.54 \%(\mathrm{w} / \mathrm{w})$, and acid-insoluble ash values were from $0.92 \pm 0.84$ to $4.19 \pm 0.75 \%(\mathrm{w} / \mathrm{w})$. Macroscopic, powder microscopy, fluorescence studies, extractive values, different properties of extracts and phytochemical screening studies were completed by a series of standard tests. The parameters evaluated under this study will safeguard the authenticity and efficacy of crude drug and provide referential information in distinguishing the drug from its adulterants. The observations of studied parameters will be useful and helpful in setting diagnostic indices for identification and preparation of monograph of this plant and in differentiating root, stem, leaf and seed of this species from closely related species of same genus and family.
\end{abstract}

Keywords Adulteration · Flavonoids · Macroscopic · Pharmacognosy · Phytochemical analysis · Standardization

\section{Introduction}

There have been substantial contributions of plant resources to human welfare. Plants have been the source of remedies against different diseases from ancient time in many traditional medicine systems and continue to serve mankind with new remedies throughout the world [53]. There are many unwanted plants also called weeds which are very common, dominant and widespread in different crop fields and occupy open spaces [36]. These are produced in a large quantity and are competing to crops for nutrients, water and light. The estimated loss caused by weeds every year is more than $24 \%$. Recently, many phytochemicals from the weeds were investigated for their therapeutic potential against many chronic diseases [16].

About twenty species are reported in genus Trianthema; these are annual or perennial plants. They are usually characterized by fleshy, opposite, unequal, smoothmargined leaves, prostrate growth form, flower with five perianth segments, and subtended by a pair of bracts. Another important feature like superior fruit having a circumscissile capsule with a winged lid and net primary production represents the biomass which is incorporated into the plant parts during a specific time interval [51]. One of the novel plants of this genus is Trianthema portulacastrum Linn. which is a prostrate, diffuse, branched,

\footnotetext{
$\triangle$ Vinay Sharma, vinaysharma30@yahoo.co.uk| 'Department of Bioscience and Biotechnology, Banasthali Vidyapith, Banasthali, Rajasthan 304022, India. ${ }^{2}$ ICBio Clinical Research Pvt. Ltd, Bangalore 560097, India. ${ }^{3}$ Amity Institute of Biotechnology, Amity University, Rajasthan, Jaipur 303002, India.
} 
glabrous, succulent annual herb and up to $30-65 \mathrm{~cm}$ length. This plant is commonly known as Biskhapra, galijeru, desert Horse Purslane, belonging to Aizoaceae family [6]. The plant and its different parts showed various applications in traditional system of medicine. The whole plant is used as laxative, antipyretic, analgesic, antidote, astringent, appetizer, diuretic, expectorant, carminative, stomachic, anti-asthmatic and cures bronchitis, itch, piles, liver diseases, night blindness, chronic ulcers, skin diseases, diseases of blood and heart and used in inflammation and rheumatism [26]. The leaves possess diuretic properties and applied for the treatment of strangury, jaundice and dropsy. The juice of the leaves dropped in the nostrils relieves migraine. The root is reported to be effective in eye corneal ulcers, itching, dimness of sight and night blindness, mild purgative or cathartic and abortion [18]. A study also reveals it as an antidote to alcoholic intoxication and is very affective in the reduction of diethylnitrosamine-induced hepatocarcinogenesis [4] and lowering effect of paracetamol- and thioacetamide-induced hepatotoxicity in rats as well as antioxidant activity [31]. Various parts of the T. portulacastrum extracts on experimental studies have been reported as antioxidant [62], antilithic, central analgesic, hepatoprotective, nephroprotective, antifertility, antihyperglycemic, antibacterial and antifungal, anthelmintic, and antihypolipidemic and anticancer activity [35].

For the past few years, scientists have changed their focus on drug development strategies to isolate and purify active biomolecules from plant sources, since these show lesser side effects in comparison with chemically synthesized drugs. Many bioactive molecules are qualitatively identified in different constituents of plant like alkaloids, flavonoids, phenols, saponins, terpenes and tannins that are the most significant [19]. Therefore, standardized procedures for the extraction of crude drugs from different parts of medicinal plant are needed to ascertain its identity and to establish its quality, purity, different extractive values, content of moisture, fluorescence study and powder microscopy [9]. There are many studies related to the therapeutic activity of this plant. However, phytochemical screening of four different parts of $T$. portulacastrum in a widerange solvent system and development of quality control parameters for the standardization of different part is still limited. This study investigates the microscopic study, pharmacognostical evaluation of plant and its fluorescence characterization, which aid in identification, adulteration and authentication of phytoconstituents that play a major role in the therapy of curing various disorders.

\section{Materials and methods}

\subsection{Procurement and authentication}

Trianthema portulacastrum L. plants were collected from local areas of Banasthali Vidyapith, Rajasthan, during December 2018. The geographical location of sampling site with latitude: $26^{\circ} 22^{\prime} 48^{\prime \prime} \mathrm{N}$, longitude: $75^{\circ} 51^{\prime} 19^{\prime \prime} \mathrm{E}$ and $314 \mathrm{~m}$ elevation from sea level. These herbs were authenticated by ethnobotanist and deposited in herbarium at the department of Bioscience and Biotechnology, Banasthali Vidyapith, Rajasthan, and the authentication number is BURI-19086/2019.

\subsection{Chemicals, reagents and solvents}

All the chemicals, regents and solvents used in this study were of analytical grade. The solvent included petroleum ether $(P E)$, benzene $(B)$, chloroform $(C)$, ethyl acetate $(E A)$, ethanol $(E)$ and distilled water $(A Q)$.

\subsection{Processing, preservation and preparation of extracts}

Fresh whole plant of T. portulacastrum L. was washed under running tap water and blot-dried. The plant material was separated into leaf, root, seed and stem, further shade-dried for nearly 3 weeks and pulverized into powder. Powder was passed through the \#40 mesh sieve and stored in airtight closed container for further analysis. All four parts of plant powder were used for the successive solvent extraction process by Soxhlation method. About $50 \mathrm{~g}$ of the dried pulverized material was uniformly packed into a thimble and extracted with $250 \mathrm{ml}$ of different solvent systems of increasing polarity, using by hot continuous extraction method in Soxhlet apparatus at a temperature of $30-85^{\circ} \mathrm{C}$. The Soxhlet extraction continues till the solvent in the siphon tube of an extractor become colorless [61]. The solvents used sequentially are petroleum ether, benzene, chloroform, ethyl acetate, and ethanol and were finally macerated with distilled water. Shade-dried powder was extracted with water by macerating $50 \mathrm{~g}$ in $250 \mathrm{ml}$ for 1 week with occasional stirring. Each time the pulverized drug material was dried in open air and subjected to further extraction. At the end of effective extraction, macerated and Soxhleted extracts were filtered using Whatman filter paper No. 1. Finally, the excess solvent was evaporated to solventlessness at $37^{\circ} \mathrm{C}$ under reduced pressure $(-760 \mathrm{mmHg})$ on a rotary evaporator (HEIDOLPH, Germany) to produce a sticky material and stored at $4{ }^{\circ} \mathrm{C}$ into sterile vials for their pharmacognostical, 
phytochemical and physiochemical screening [33]. The percentage of extractive yield is calculated by formula [30] as mentioned below.

$\%$ Extraction yield $(w / w)$

$$
=\frac{\text { Weight of dried extract }}{\text { Weight of the Sample used for extraction }} \times 100
$$

\subsection{Organoleptic evaluation}

Organoleptic evaluation is an important step for the identification of any adulterant in the medicinal plant. It refers to sensory evaluation, and the characteristics are evaluated such as color, odor, size, taste, shape and texture [29].

\subsection{Powder microscopy}

The dried powders of root, stem, leaf and seeds were observed under high-power (10X, 40X) microscope (Metzer) with stain (safranin and fast green) and without stain, mounted in glycerin, and various diagnostic characters such as stoma, trichomes, lignified fibers, xylem, sclereids are studied $[21,29,40]$.

\subsection{Physicochemical analysis}

The physicochemical parameters such as percentage of total ash value, acid-insoluble ash, water-soluble ash value, extractive values, foreign organic matter, loss on dryness (LOD), $\mathrm{pH}$ analysis and fluorescence study are the deciding factors to evaluate purity, quality and adulteration of crude drugs. All the analysis was performed according to WHO guidelines [3, 12].

\subsection{Phytochemical screening}

Preliminary qualitative phytochemical screening of different solvent extracts of crude powder of four different parts of T. portulacastrum was carried out to identify different phytoconstituents by using standard conventional procedures [47]. The presence and absence of phytochemicals are indicated with signs " + " and "-", respectively.

\section{Results and discussion}

\subsection{Organoleptic characters}

Organoleptic analysis helps to assess the physical and chemical quantity of plant sample. T. portulacastrum L. grows in a verity of habitat as weed. It is an annual herbforming prostrate mat or club with a meter-long stem. It has glabrous surface and smooth slightly succulent texture, and features are represented in Table 1 and Fig. 1.

\subsection{Powder microscopy}

The fine powder of root, stem, seed and leaf was mounted in glycerin and treated with lactophenol before staining with iodine, phloroglucinol $+\mathrm{HCl}$ and Sudan III. Various micro-morphological features observed in different parts of plant powder and revealed numerous square-, prismatic-, polygonal-, rosette-shaped calcium oxalate crystals in root, stem, leaf and seed powders. Different arrangements of trichomes are observed with xylem vessels and
Table 1 Organoleptic and morphological features of $T$. portulacastrum $\mathrm{L}$.

\begin{tabular}{ll}
\hline Parameters & Observations \\
\hline Color & Dark green areal surface with pink to red margins leaf \\
Taste & Leaf-Bitter, root-faint, stem—-bitter \\
Odor & Aromatic \\
Shape & Succulent, glabrous, pubescent herb with spread branches \\
Leaf & Subfleshy, obliquely opposite unequal or subopposite, \\
& $1.2-3.5 \times 0.8-2.2 \mathrm{~cm}$, stipulate with truncate base, entire \\
Size & wavy margin and apiculate apex \\
Stem & Middle leaflet and 6-12 cm long \\
Stomata & Green to brown, a meter long \\
Flowers & Anomocytic \\
Seeds & 7 mm across, axillary, solitary, sessile, calyx tube 1.5 mm long \\
& Black with muricate concentric lines, one seed may be \\
& carried on the detached cap of the fruit, other seeds may \\
& fall out of the remaining part of the fruit or remain on the \\
& plant after it dies \\
\hline
\end{tabular}




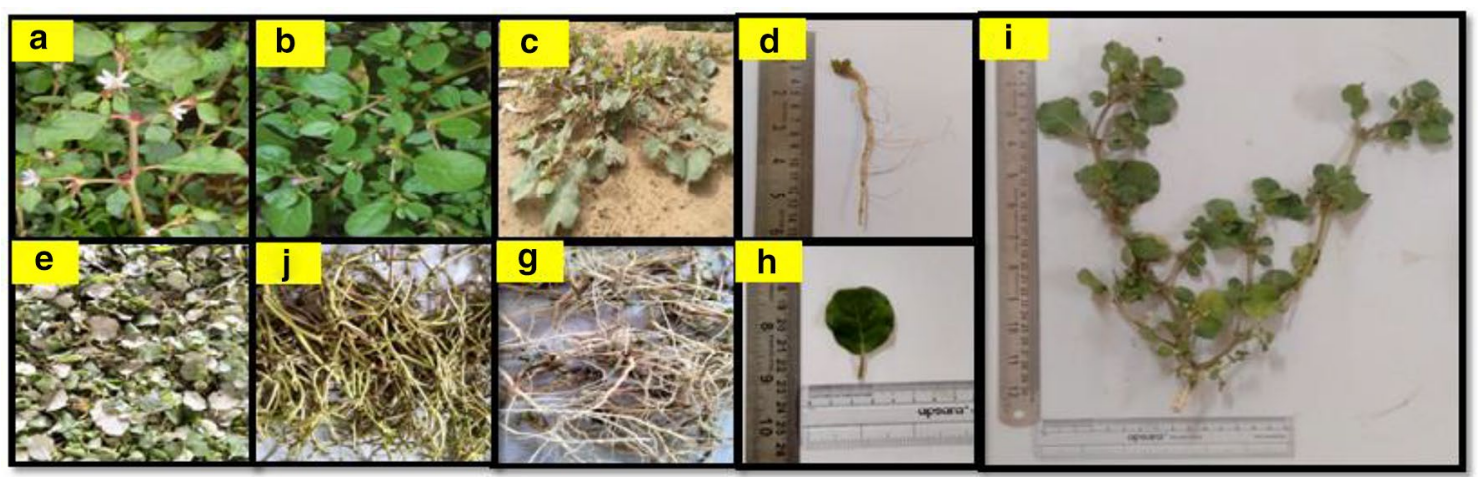

Fig. 1 a-c, i Plant, e, $\mathbf{h}$ leaf, $\mathbf{f}$ stem, $\mathbf{d}, \mathbf{g}$ root-organoleptic and morphological features of T. portulacastrum L.

lignified fibers. Powders also manifest the presence of various lactiferous granules, polyhedral or sharp angles starch grains in stem, root and leaf and oil bodies and aleuronic grains in seeds. Epidermal cells, stomatal openings, spongy parenchyma, vittae-volatile contain schizogenous cells; somewhat irregular shaped parenchymatous cells were also observed in leaf powder microscopy, as represented in Fig. 3.

\subsection{Physicochemical analysis}

Evaluation of different physicochemical parameters is an important tool in detecting adulteration or improper handling of drugs. Physicochemical characterization of powder of studied parts of $T$. portulacastrum $\mathrm{L}$. is represented in Figs. 2, 4.

\section{$3.4 \mathrm{pH}$ analysis}

The $\mathrm{pH}$ values of different parts of the plant powder of $1.0 \%(\mathrm{w} / \mathrm{v})$ were slightly acidic in the range of 6.0 to 6.8 , for root 6.8, for stem 6.1, for leaves 6.0 and for seeds 6.4. The $\mathrm{pH}$-acceptable range of fruits, vegetable, grasses, flowers, trees, shrubs and annual is 4.0-7.5, while that of food is given as $\mathrm{pH} 2.0-9.0$ [59]. According to various guidelines, biopharmaceutical characteristics of drugs are depend on acid/base properties, and moreover, absorption, distribution, metabolism, extraction and toxicity (ADMET) are profoundly affected by the charge state of compounds under varying $\mathrm{pH}$ conditions. Indeed, acid/base character affects drug potency and selectivity and has a great impact on both pharmacokinetic and biopharmaceutical properties [34] (Fig. 3).

\subsection{Loss on drying (LOD)}

The percentage of weight loss on drying or moisture content at $105^{\circ} \mathrm{C}$ of root, stem, leaf and seed is, respectively, $6.2 \pm 0.58,7 \pm 0.73,5.7 \pm 0.43$ and $2 \pm 0.69 \%$ of $T$. portulacastrum L. Moisture content of drug should be at minimum level to discourage the growth of bacteria, yeast or fungi during storage. Low moisture content

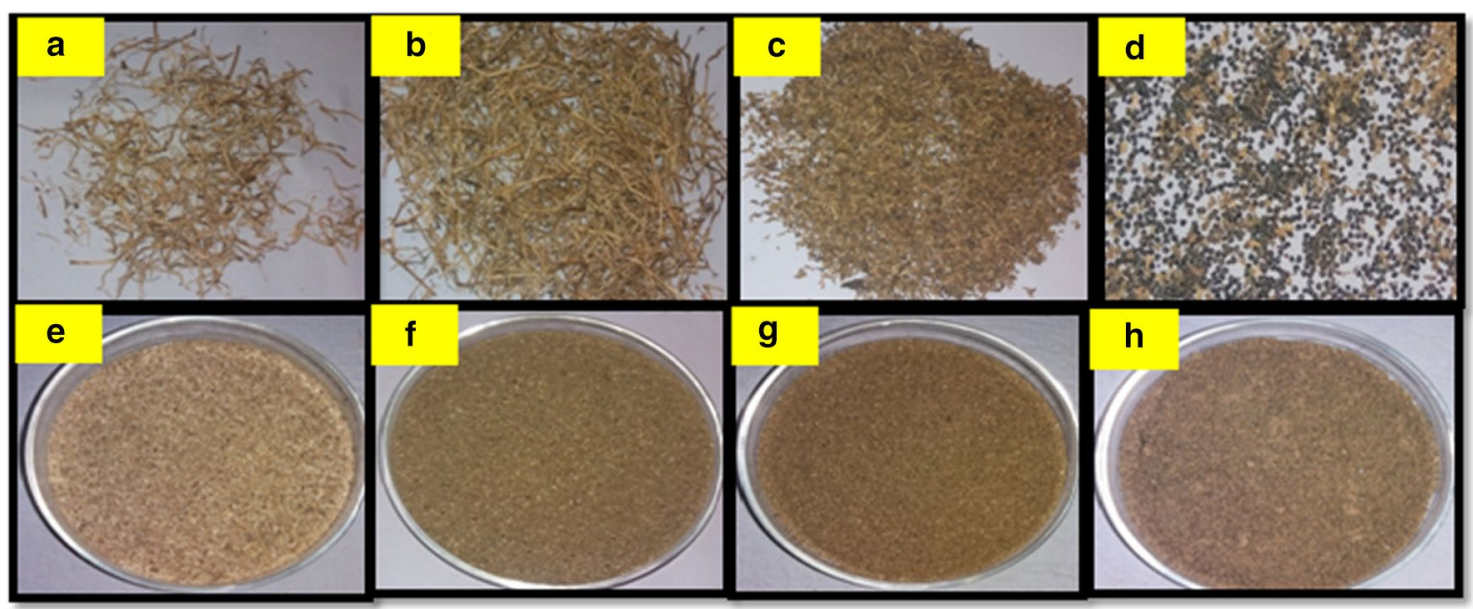

Fig. 2 Shade-dried parts of T. portulacastrum L. a Root, b stem, c leaf, $\mathbf{d}$ seed and powdered form, e root, $\mathbf{f}$ stem, $\mathbf{g}$ leaf, $\mathbf{h}$ seed 


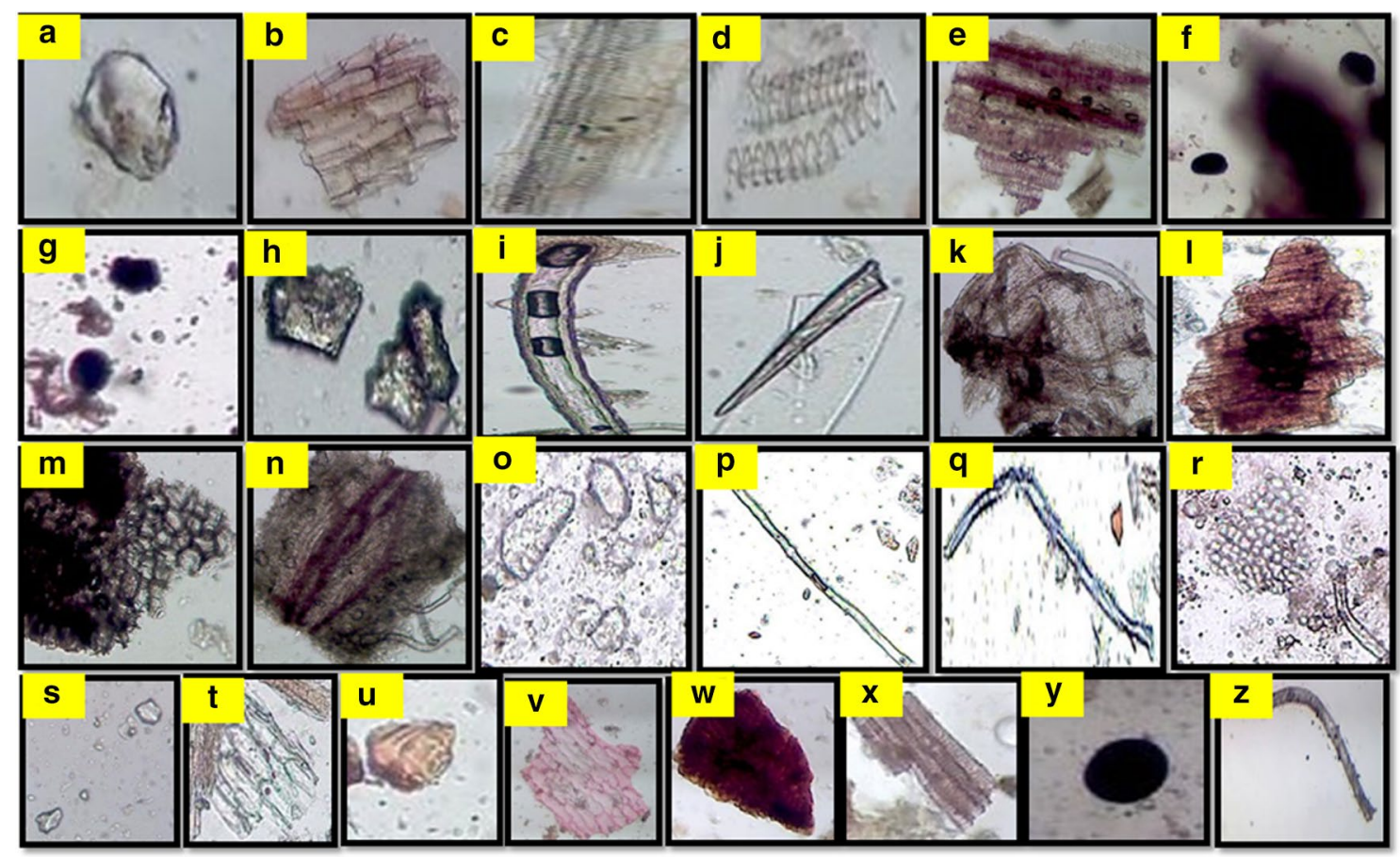

Fig. 3 Powder study T. portulacastrum L. Root-(a calcium oxalate crystal, b lignified cells, c reticulate xylem vessels, d spiral xylem vessels, e lignified cells with spiral vessels, $\mathbf{f}$ starch granules); stem-( $\mathbf{g}$ starch granules, $\mathbf{h}$ calcium oxalate crystals, i phloem fiber, j trichome, $\mathbf{k}$ cork cells, I lignified cells, $\mathbf{m}$ spongy cells, $\mathbf{n}$ embedded

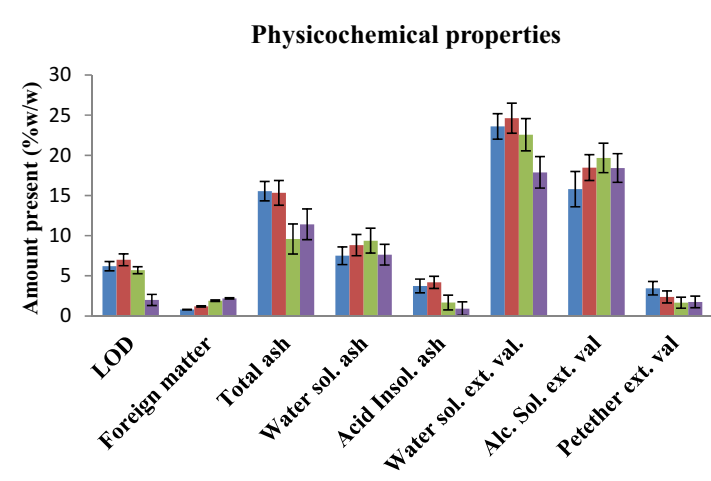

Fig. 4 Evaluation of different physiochemical properties of T. portulacastrum $\mathrm{L}$.

indicates the appropriate standard, quality and stability of plant material and can be considered in future study or application. If the drying process is not efficient, it may lead to the degradation of phytoconstituents of the drug during storage [17]. Deterioration period of the crude drug powder is dependent on the presence of water quantity in plant material. High water content may easily support the growth of fungal colonies and lead to interfere with the quality of drug easily [33]. The
Ca-oxalate crystals); seed-(o Ca-oxalate crystals, $\mathbf{p}$ epidermal fiber, $\mathbf{q}$ trichome, $\mathbf{r}$ polygonal cellulosic oil globules and aleurone grains); leaf-(s Ca-oxalate crystals, $\mathbf{t}$ spongy parenchyma, $\mathbf{u}$ stone cells, $\mathbf{v}$ cork cells, w lignified cells, $\mathbf{x}$ spiral xylem vessels, $\mathbf{y}$ starch granule, $\mathbf{z}$ trichome)

present study supported the previous investigations of same plant where loss on drying was reported as $9.5 \%$ [40]. The present investigations made on each part of T. portulacastrum L., where minimum LOD was found in seed with respect to root, stem and leaf. This indicates that drying process was efficient, loss on drying for leaves of $10.7 \%$ for Gynura segetum [49] and $8.8 \%$ for Garcinia indica [44].

\subsection{Foreign matter}

Foreign organic matters recorded in the powder of four different parts of plant under study were $0.8 \pm 0.045$, $1.2 \pm 0.75,1.9 \pm 0.089$ and $2.0 \pm 0.081$ for root, stem, leaf and seed, respectively. In the present study, the amount of foreign organic matter detected was low as per WHO [60].

\subsection{Ash values}

The ash value of all the four parts of plant under study was determined by three different forms, viz. total ash, water-soluble ash and acid-insoluble ash, and the results are presented in Fig. 4. The total ash values for root, 
stem, leaf and seed were determined as $15.54 \pm 1.21$, $15.54 \pm 1.21,9.59 \pm 1.87$ and $11.41 \pm 1.91 \%$, respectively. The water-soluble ash values were $7.5 \pm 1.10,8.83 \pm 1.32$, $9.38 \pm 1.54$ and $7.64 \pm 1.29 \%$ for root, stem, leaf and seed, respectively, while, acid-insoluble ash values for root, stem, leaf and seed were $3.74 \pm 0.85,4.19 \pm 0.75,1.68 \pm 0.92$ and $0.92 \pm 0.84 \%$, respectively. The ash values were in accordance with earlier study about this plant and comparable to such studies for other plants. Total ash value was reported as $11.83 \%$, water-soluble ash as $1.5 \%$ and acid-insoluble ash as $0.83 \%$ [40] and total ash value $22 \%$, water-soluble ash value $13 \%$ and acid-insoluble ash value as $2 \%$ [2] for leaf T. portulacastrum. The present investigation also supports the earlier reports on Boerhavia diffusa L. [55]. The ash values of the drug are also a significant parameter for the detection of nature of material, adulteration, impurities, authenticity of drug, quality and purity of the test sample. The total ash value indicates the impurities like carbonate, oxalate and silicate. The content of inorganic compounds in the drug is represented by the water-soluble ash values. The acid-insoluble ash is used to estimate the amount of silica present, especially sand which is the indication of contamination with earthy material [46]. Relatively less amount of these three parameters indicate low inorganic matter and silica were detected in root, stem, leaf and seed powders of T.portulacastrum $\mathrm{L}$.

\subsection{Extractive values}

The extractive values of different parts of T. portulacastrum are manifested in Fig. 4. The highest extractive value was found in water followed by alcohol and minimum extractive value in petroleum ether. So far, as the different parts of plant are concerned, stem shows the highest water extractive value followed by root, leaf and seed. The maximum alcohol extractive value was in leaf powder followed by stem, seed and root. All the four parts had shown minimum petroleum ether extractive values. The extractive values of organic solvent of T. portulacastrum were found in the range of 1.66 to $22.5 \%$. The above results indicate the presence of higher amount of polar compounds than nonpolar. The present investigation also supports the earlier reports on T. portulacastrum and other such plants. The range of extractive value from $0.54 \%$ in petroleum ether to $10.94 \%$ in methanol and water extractive value was reported as $7.93 \%$ in halophyte Cyperus conglomerates [40]. In other such study of T. portulacastrum, watersoluble extractive value, alcohol-soluble extractive value and chloroform-soluble extractive value were reported as $37.6 \%, 8.8 \%$ and $3.2 \%$, respectively [2]. The extractive value ranged from 0.52 to $8.64 \%$, and water-soluble extractive value $17.7 \%$ reported in T. portulacastrum [41]. The alcoholsoluble extractive value and water-soluble extractive value of $Z$. armatum were reported to be $14.66 \%$ and $10.33 \%$, respectively [58]. The alcohol-soluble extractive value and water-soluble extractive value of Moringa Oleifea leaves were reported as $13.20 \%$ and $08.63 \%$, respectively [20].

When the chemical composition of drug cannot be easily estimated by any other means [24], the extractive values can be important tool to evaluate and identify the chemical constituents present in the crude drug and helpful in estimating the chemical proportions soluble in a particular solvent system [25]. The amount of extract yield in a solvent system is often an approximate measure of the amount of certain constituents that drug contains. High water-soluble extractive value indicates the presence of acids, sugars and inorganic compounds, and high alcoholsoluble extractive value indicates the presence of polar constituents such as steroids, phenolics, flavonoids and glycosides [52].

\subsection{Fluorescence study}

The powder of root, stem, leaf and seed of T. portulacastrum showed different behaviors recorded upon treatment with different chemical reagents. The root, stem, leaf and seed powders as such showed dark brown to light brown, whereas when they are treated with $1 \mathrm{~N} \mathrm{NaOH}$, root turned into lemon green, stem turned into light yellow, leaf turned into green and seed turned into light green. When they were treated with $1 \mathrm{M} \mathrm{HCl}$ and concentrated $\mathrm{HCl}$, the root powder turns into colorless and light brown, respectively, and it was observed as fluorescent blue and light brown under UV (low $254 \mathrm{~nm}$ and high $365 \mathrm{~nm}$ ), stem turned into light brown and dark brown, respectively, and was light green and dark brown under UV, leaf turned into light brown and black, respectively, and was light brown and black under UV, seed turned into light brown and brown, respectively, and observed as fluorescent blue and dark brown under UV. These drugs were treated with $40 \% \mathrm{NaOH}+10 \% \mathrm{CH}_{3} \mathrm{COOPb}$ : the root powder turns into yellow and under UV it turned into light yellow; stem turned into brown and was light brown under UV; leaf turned into yellow and under UV it was light brown; and seed turned into light brown and was fluorescent blue and dark brown under UV. When these drugs were treated with concentrated acetic acid, the root powder turns into colorless and it was fluorescent blue under UV; stem turned into lemon yellow and under UV it was light brown; leaf turned into green and was light brown under UV; and seed turned into yellowish green and under UV it was brown. Likewise, the fluorescence characteristics of powdered root, stem, leaf and seed after treatment with different reagents emitted various color radiations under ultraviolet and ordinary light which are tabulated in Table 2. 
The fluorescence study is a simple, useful and one of the rapid methods to evaluate pharmacognostic properties of crude drugs. This is a valuable analysis tool that can authenticate the identification and recognition of adulterants of crude drugs. Different plant parts in powder form are examined with various nonpolar to polar reagents [64]. The colors produced by the powdered drug in the presence of different reagents represent the presence of active constituents in visible range in daylight. The fluorescence characteristics are very distinctive and distinguishing features for the determination of a drug. Some of the bioactive compounds like alkaloids produce fluorescence under UV, which does not fluoresce during normal daylight. Some other components of drug may be converted into fluorescent derivatives in the presence of different chemical reagents [42]. Therefore, fluorescence study is the most important parameter to assess the pharmacognostic property of crude drug qualitatively. The present investigation also supports the earlier fluorescence analysis for other plants such as Trichosanthes dioica [28], Terminalia arjuna, [15] and Abutilon indicum L. [11].

\subsection{Solvent extraction and yield}

The extracts of T. portulacastrum were prepared by hot continuous Soxhlet extraction method using solventspetroleum ether, benzene, chloroform, ethyl acetate, ethanol and aqueous with the ascending order of polarity $0.0,2.7,4.1,4.4,5.2$ and 9.0, respectively. The percentage $\mathrm{w} / \mathrm{w}$ yields of all the six extracts for four different parts of the plant under study were calculated and tabulated. The color, nature, consistency and physical appearance of each of six extracts for four different parts of T. portulacastrum are represented in Figs. 5, 6 and Table 3. For six different extracts of root, their colors varied from light brown, green to off white, consistency from sticky to dry, nature of extracts was solid to semisolid and \%w/w yields minimum in ethyl acetate $(0.67 \%)$ and maximum in aqueous (18.39\%). The extracts of stem color, consistency, physical state varied from dark green to brown, from sticky, oily to dry and solid to semisolid, respectively, and minimum $\% \mathrm{w} / \mathrm{w}$ yield of chloroform was $0.42 \%$ and maximum $\% \mathrm{w} / \mathrm{w}$ yield of aqueous $13.83 \%$. The extracts of leaf color, consistency, physical state varied from green to dark brown, from dry, sticky to oily and solid to semisolid, respectively, and minimum $\% \mathrm{w} / \mathrm{w}$ yield of chloroform was $0.23 \%$ and maximum \%w/w yield of aqueous $25.15 \%$. The extracts of seed color, consistency, physical state varied from light green to light brown, from sticky to dry and solid to semisolid, respectively, and minimum \%w/w yield of benzene was $0.72 \%$ and maximum $\% \mathrm{w} / \mathrm{w}$ yield of aqueous $21.43 \%$.

Successful isolation and determination of bioactive compound from the experimental plant largely depend on the selection of solvent system used in the extraction procedure. Ideal solvent for the extraction process includes low boiling point, low toxicity and preservative action and does not degrade the complex extract. There are other factors which affect the choice of solvent such as quantity of phytochemicals extracted, diversity of different compounds in extracts, rate of extraction, diversity of inhibitory compounds in extract, ease of handling of extract, potential health hazard and toxicity of solvent in the bioassay [33]. High \% yield of extract was detected with ethanol and water due to their higher polarity than others, and ethanol was found easier to penetrate the cellular membrane to extract intracellular ingredients from the test plant material [13]. During each cycle, a portion of the nonvolatile compound dissolves in the solvent. After many cycles, the desired compound is concentrated in the distillation flask. Usually, for longer time solvent and solute remain in contact to each other and therefore favor the system to have maximum mass transfer and finally reach to an equilibrium following the Fick's second law of diffusion [10]. The advantage of Soxhlet system is that single batch of solvent is recycled multiple times through the sample leading to maximum dissolution of plant bioactive compounds. Prolong heating can degrade such compounds in this system; therefore, the method is not suitable for thermolabile drug extraction. At the same time, maceration is suitable for thermolabile compound extraction [57]. The present study also supports the earlier solvent extraction of crude drug and \%yield analysis on other medicinal plants such as Azadirachta indica [8], Spondias purpurea [10] and Mangifera indica [39].

\subsection{Phytochemical screening}

The qualitative phytochemical screening of different solvent extracts from root, stem, leaf and seed powder of $T$. portulacastrum plant is arranged in Table 4. Primary metabolites present in different solvent extracts of root, viz. fixed oil in PE and B extract, amino acids and fixed oil in $C$ extract, amino acids in EA extract, protein, amino acids and carbohydrates in E extract and protein, amino acids, carbohydrates in AQ extract. So far, secondary metabolites in different solvent extracts of root are concern maximum polyphenolics present in $E$ extract followed by $E A$ and $A Q$ extracts, trace amount of flavonoids in $E A$ and $A Q$ extracts, saponin in $E A, E$ and $A Q$ extracts, tannin in $B, E$ and $A Q$ extracts, terpenoids in $E$ and $A Q$ extracts and terpenoids in $E A$ and $A Q$ extracts. Primary metabolites are present in different solvent extracts of stem, viz. fixed oil in $E$ and $A Q$ extracts, appreciable amino acids and protein in $E A$ extract, moderate in $\mathrm{E}$, amino acids in $\mathrm{EA}$ extract, protein, amino acids and carbohydrates in $E$ and $E A$ extracts and trace in $\mathrm{PE}, \mathrm{B}$ and $\mathrm{C}$ extracts. So far, secondary metabolites 


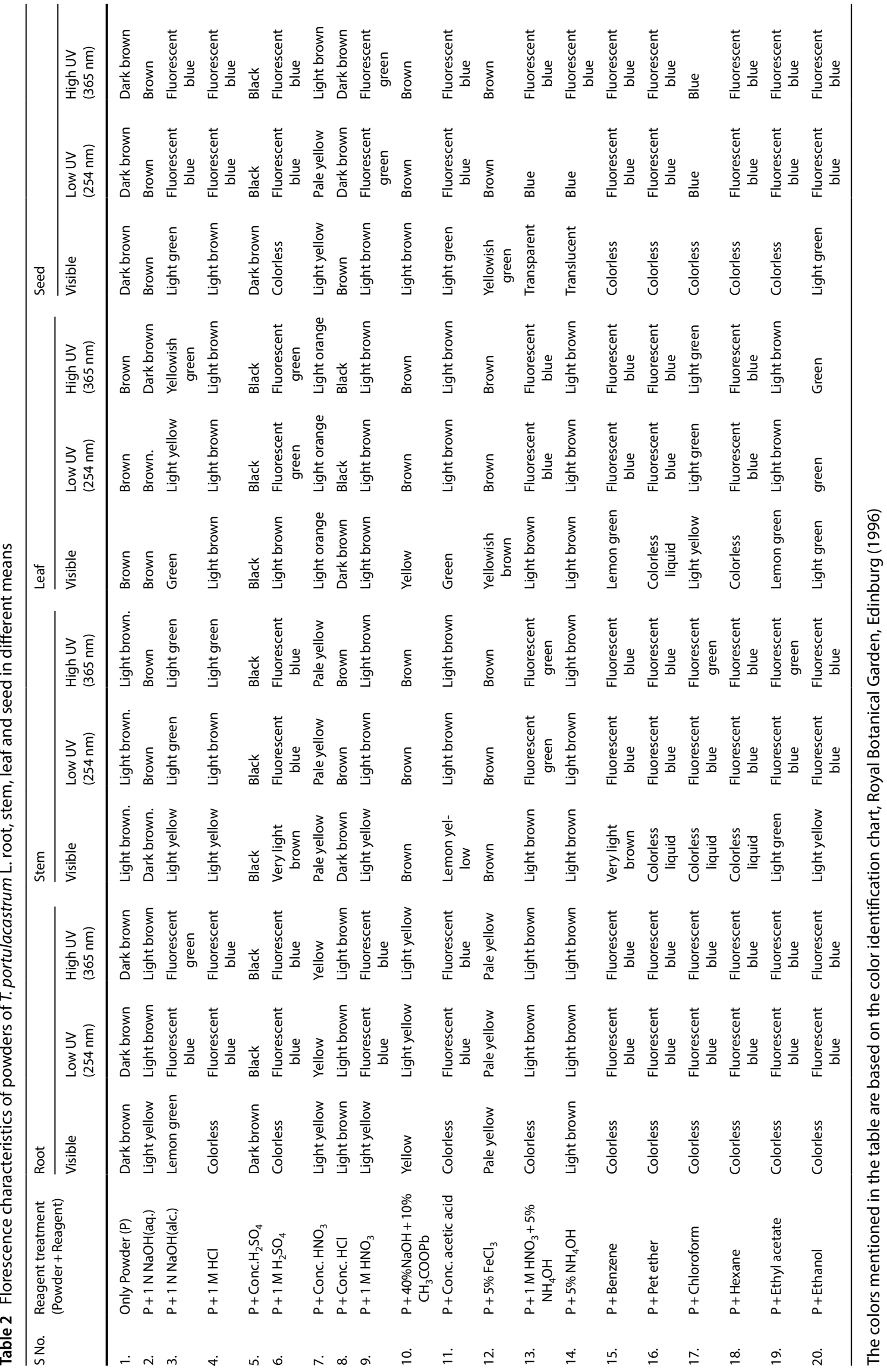




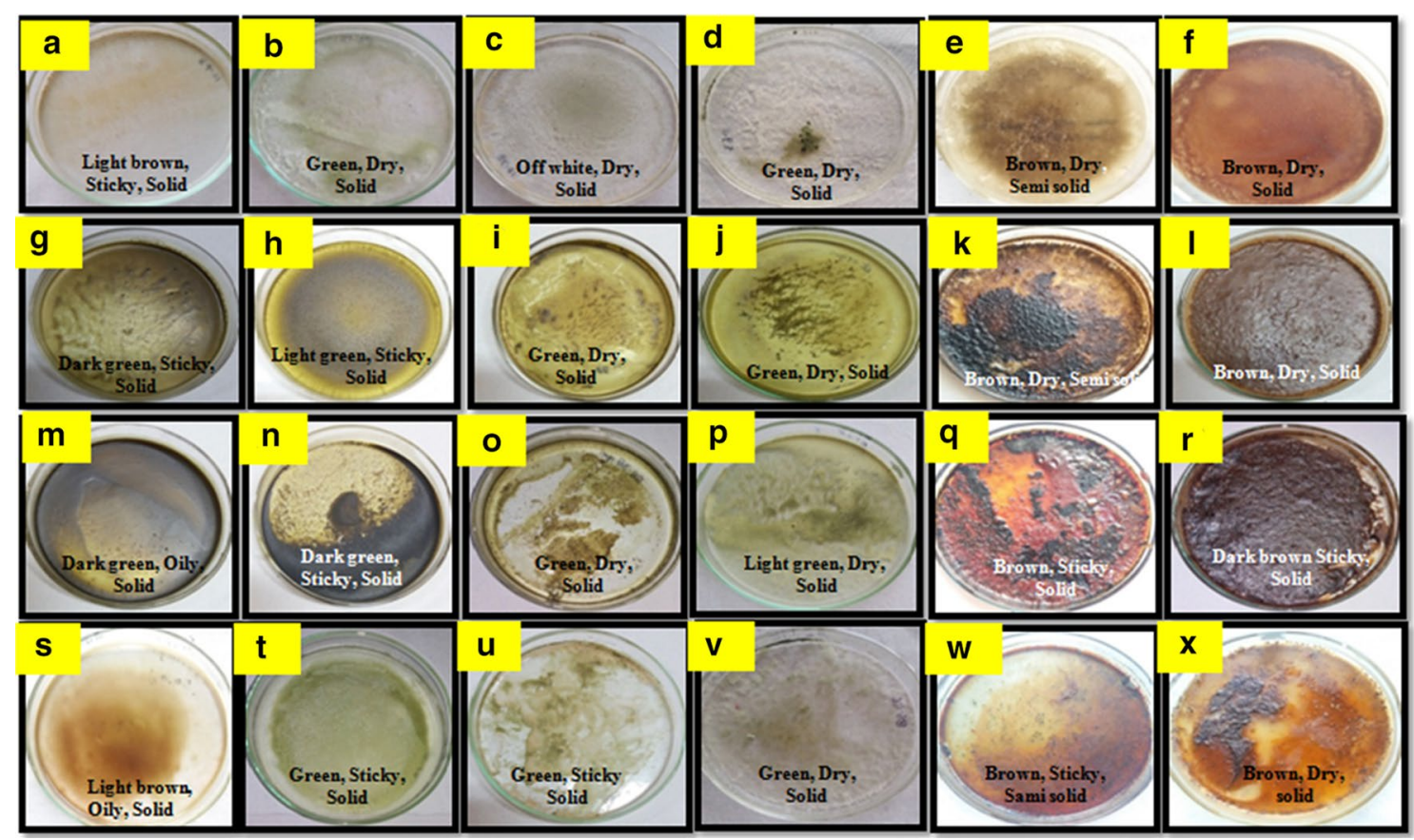

Fig. 5 Sequential extracts of T. portulacastrum root-(a pet. ether extract, b benzene extract, c chloroform extract, $\mathbf{d}$ ethyl acetate extract, e ethanol extract, $\mathbf{f}$ aqueous extract); stem-(g pet. ether extract, $\mathbf{h}$ benzene extract, $\mathbf{i}$ chloroform extract, $\mathbf{j}$ ethyl acetate extract, $\mathbf{k}$ ethanol extract, I aqueous extract); leaf-(m pet. ether extract, $\mathbf{n}$ benzene extract, $\mathbf{o}$ chloroform extract, $\mathbf{p}$ ethyl acetate extract, $\mathbf{q}$ ethanol extract, $\mathbf{r}$ aqueous extract); seed-( $\mathbf{s}$ pet. ether extract, $\mathbf{t}$ benzene extract, $\mathbf{u}$ chloroform extract, $\mathbf{v}$ ethyl acetate extract, $\mathbf{w}$ ethanol extract, $\mathbf{x}$ aqueous extract)
Fig. 6 Crude extracts of different parts of $T$. portulacastrum $\mathrm{L}$. root, stem, leaf and seed

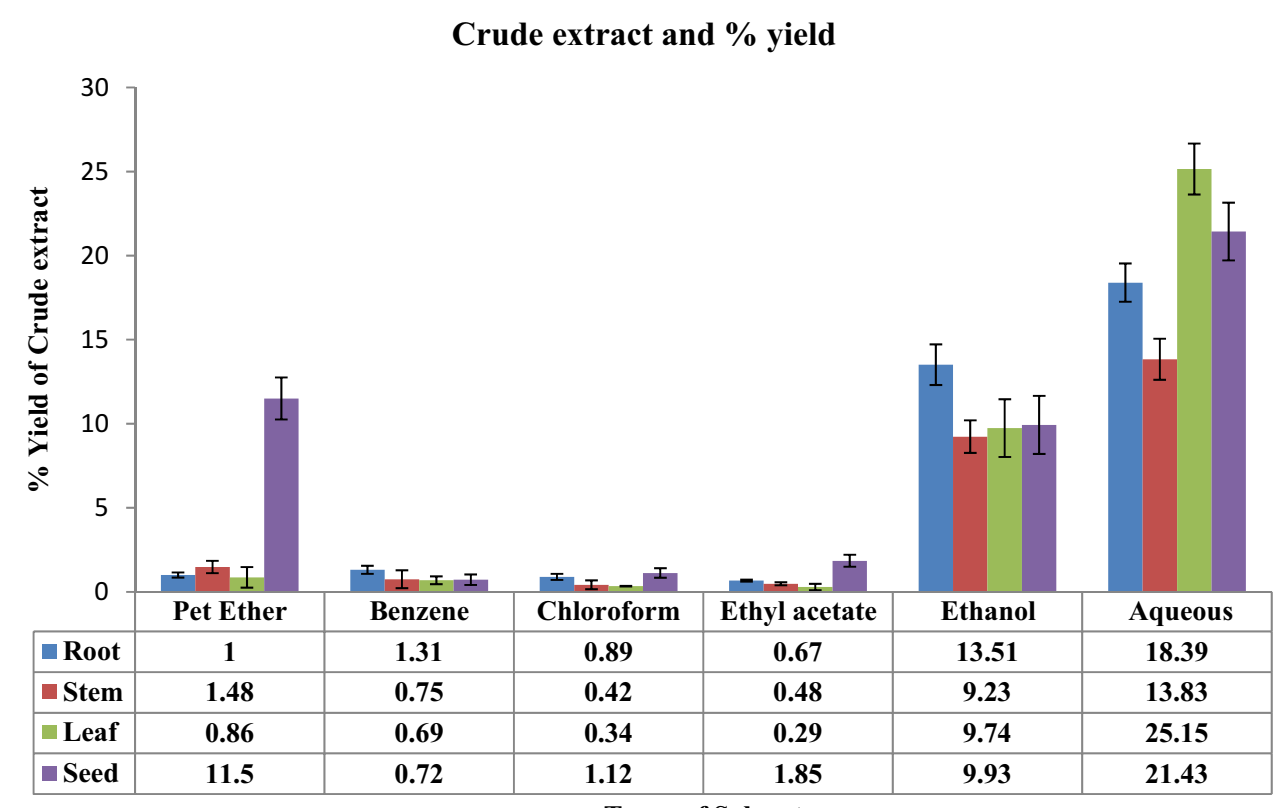

Types of Solvent in different solvent extracts of stem are concern appreciable polyphenolics present in $\mathrm{E}$ and $\mathrm{AQ}$ extracts, moderate flavonoids in $E A, E$ and $A Q$ extracts, appreciable saponin in $E$ and trace in $E A$ and $C$ extracts, moderate tannin in $B$ and trace in $\mathrm{C}, \mathrm{EA}$ and $\mathrm{E}$ extracts, moderate terpenoid in $\mathrm{PE}, \mathrm{B}$,
C, EA and E extracts, trace alkaloid, anthraquinone in $\mathrm{AQ}$ extract and moderate glycosides in AQ. Primary metabolites are present in different solvent extracts of leaf, viz. fixed oil in PE, C, EA, E and AQ extracts, trace amino acids and protein in $E A$ and $E$ extracts and trace carbohydrates 
Table 3 Properties of crude extracts in different solvent systems T. portulacastrum L. root, stem, leaf and seed

\begin{tabular}{|c|c|c|c|c|c|c|c|}
\hline Plant parts & Solvents & $\begin{array}{l}\text { Extraction } \\
\text { method }\end{array}$ & Extract color & Consistency & Nature of extracts & Extract weight (g) & $\%$ Yield \\
\hline \multirow[t]{6}{*}{ Root } & PE & $S$ & Light brown & Sticky & Solid & $0.05 \pm 0.01$ & $1.0 \pm 0.15$ \\
\hline & B & $S$ & Green & Dry & Solid & $0.06 \pm 0.01$ & $1.31 \pm 0.24$ \\
\hline & $\mathrm{C}$ & $S$ & Off white & Dry & Solid & $0.04 \pm 0.01$ & $0.89 \pm 0.18$ \\
\hline & EA & $\mathrm{S}$ & Green & Dry & Solid & $0.03 \pm 0.01$ & $0.67 \pm 0.06$ \\
\hline & $E$ & $S$ & Brown & Dry & Semi solid & $0.60 \pm 0.03$ & $13.51 \pm 1.21$ \\
\hline & $\mathrm{Aq}$ & M & Brown & Dry & Solid & $3.06 \pm 0.27$ & $18.39 \pm 1.14$ \\
\hline \multirow[t]{6}{*}{ Stem } & $\mathrm{PE}$ & $\mathrm{S}$ & Dark green & Sticky & Solid & $0.74 \pm 0.16$ & $1.48 \pm 0.37$ \\
\hline & B & $S$ & Light green & Sticky & Solid & $0.37 \pm 0.07$ & $0.75 \pm 0.53$ \\
\hline & C & $S$ & Green & Dry & Solid & $0.20 \pm 0.06$ & $0.42 \pm 0.26$ \\
\hline & EA & $\mathrm{S}$ & Green & Dry & Solid & $0.22 \pm 0.08$ & $0.48 \pm 0.09$ \\
\hline & $\mathrm{E}$ & $\mathrm{S}$ & Brown & Dry & Semi solid & $3.76 \pm 0.19$ & $9.23 \pm 0.23$ \\
\hline & $\mathrm{Aq}$ & M & Brown & Dry & Solid & $5.44 \pm 0.31$ & $13.83 \pm 1.22$ \\
\hline \multirow[t]{6}{*}{ Leaf } & $\mathrm{PE}$ & $\mathrm{S}$ & Dark green & Oily & Solid & $0.43 \pm 0.03$ & $0.86 \pm 0.61$ \\
\hline & $\mathrm{B}$ & $S$ & Dark green & Sticky & Solid & $0.34 \pm 0.04$ & $0.69 \pm 0.23$ \\
\hline & $C$ & $S$ & Green & Dry & Solid & $0.11 \pm 0.03$ & $0.23 \pm 0.02$ \\
\hline & $\mathrm{EA}$ & $S$ & Light green & Dry & Solid & $0.13 \pm 0.02$ & $0.29 \pm 0.19$ \\
\hline & $E$ & $\mathrm{~S}$ & Brown & Sticky & Solid & $4.25 \pm 0.85$ & $9.74 \pm 1.72$ \\
\hline & $\mathrm{Aq}$ & M & Dark green & Dry & Semi Solid & $9.03 \pm 1.35$ & $25.15 \pm 1.52$ \\
\hline \multirow[t]{6}{*}{ Seed } & PE & $S$ & Light brown & Oily & Solid & $1.15 \pm 0.03$ & $11.5 \pm 1.25$ \\
\hline & B & $S$ & Green & Sticky & Solid & $0.06 \pm 0.02$ & $0.72 \pm 0.31$ \\
\hline & C & $S$ & Green & Sticky & Solid & $0.09 \pm 0.02$ & $1.12 \pm 0.28$ \\
\hline & $\mathrm{EA}$ & $\mathrm{S}$ & Green & Dry & Solid & $0.14 \pm 0.03$ & $1.85 \pm 0.36$ \\
\hline & $E$ & $\mathrm{~S}$ & Brown & Sticky & Semi solid & $0.75 \pm 0.06$ & $9.93 \pm 1.73$ \\
\hline & $\mathrm{Aq}$ & $M$ & Brown & Dry & Solid & $1.46 \pm 0.38$ & $21.43 \pm 1.78$ \\
\hline
\end{tabular}

$P E$ petroleum ether, $B$ benzene, $C$ chloroform, $E A$ ethyl acetate, $E$ ethanol, $A q$ aqueous, $M$ maceration, $S$ Soxhlation, $E x$ extraction

in $\mathrm{E}$ and $\mathrm{EA}$ extracts. So far, secondary metabolites in different solvent extracts of stem are concern appreciable glycosides in B extract, appreciable polyphenolics in E extract, moderate polyphenolics in $\mathrm{AQ}$ and $\mathrm{C}$ extracts, trace polyphenolics in $E A$ extract, appreciable saponin in $E$ and $A Q$ extracts, moderate saponin in EA extract, moderate-free sugars in $\mathrm{E}$, trace flavonoids in $\mathrm{B}$ extract, moderate tannin in $B$ extract, trace tannin in $\mathrm{PE}, \mathrm{C}$ and $\mathrm{E}$ extracts, moderate terpenoids in $\mathrm{PE}, \mathrm{EA}$ and $\mathrm{E}$ extracts and trace terpenoid in $C$ extract. Primary metabolites are present in different solvent extracts of seed, viz. trace carbohydrate in $C$ and $A Q$ extracts and trace fats in $B, C, E A, E, A Q$ extracts. So far, secondary metabolite in different solvent extracts of seed are concern trace alkaloid in $C$ and $A Q$ extracts, cardiac glycosides in $E$ and $A Q$ extracts, trace flavonoids in $E$ and $A Q$ extracts, moderate polyphenolics in $E$ and $A Q$ extracts, trace saponin in $E A, E$ and $A Q$ extracts, moderate tannins in E extracts, trace terpenoid in $B$ and $C$ extracts and moderate terpenoid in $\mathrm{E}$ extract.

The qualitative phytochemical screening of medicinal plants is an important parameter of quality control.
So it is a necessary step in the study of pharmacognostic attribute of the plant that may be used in the protection against chronic diseases, pharmaceutical formulation and further research [27]. Phytochemical studies performed on different plant extracts reveal the presence of bioactive molecules which were known to possess medicinal and physiological activities. Different solvent extracts of different parts of plant analysis revealed the presence of various types of phytoconstituents in different amounts that help in the selection of specific extract for isolating the active principle [48]. The pharmacological activity studies are not part specific of medicinal plant rather all organs are important and evaluated for various therapeutic efficacies of plant such as leaf of Ageratum conyzoids and Homalium ceylanium [1, 7, 22], root of Argyreia pilosa [45], stem of Psychotria rubra and Acacia auriculiformis [38, 50, 56], bark of Chloroxylon swietenia [14], fruit of Benincasa Hispida [37], flower of Woodfordia fruticosa [5], seed of Aegle marmelos [42], aerial parts of Heracleum persicum and Achyranthes aspera [54, 63], rhizome [23] and pseudobulbs of Coelogyne cristata [43]. 


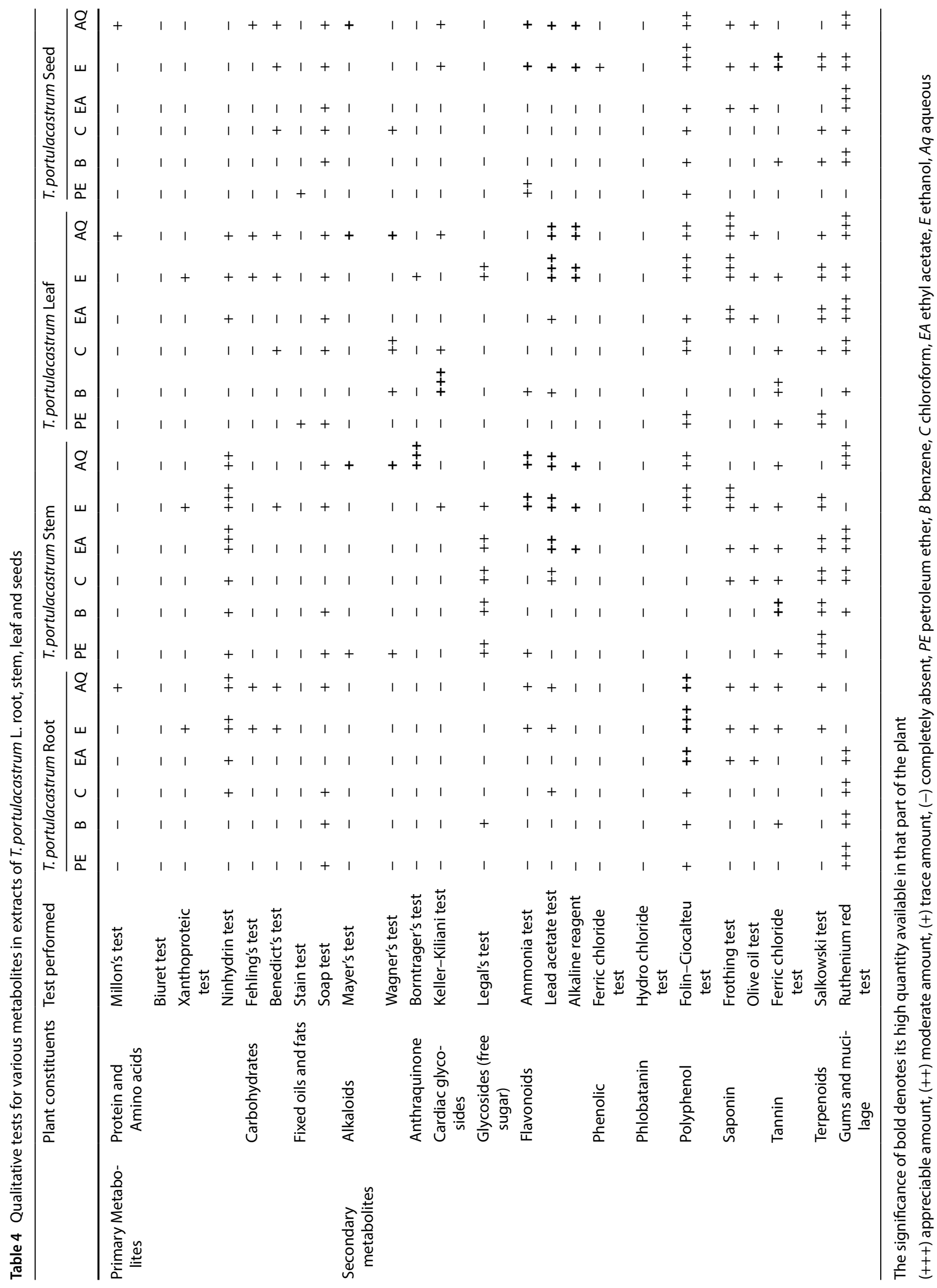


T. portulacastrum thus comes across their therapeutic values due to the presence of respective phytochemical constituents. Various phytoconstituents present in different parts of this plant revealed that it can be a rich source of new drugs for various ailments.

\section{Conclusion}

There is no detailed and comparative physicochemical and phytochemical screening work of four different parts of $T$. portulacastrum $\mathrm{L}$. which has been reported till date. Different parts of this plant have been used in traditional system of medicine. Although herbal drugs are well known for their safe action, they may lead to adverse reactions and may be due to incorrect identification and adulteration of crude drug. Therefore, the aim behind this study was to establish quality control, standardization and genuineness of drugs. Macroscopic and microscopic study of plant part will help in correct identification of drug. The comparative extractive values and ash values will be helpful in determining quality of drug material. The fluorescence study and phytochemical screening will support in analyzing the purity of the drug. The present investigations were taken up with a view to facilitate herbal industries and traditional medicinal people to establish the standards, authenticity of drug, quality, purity, pharmacological benefits, diverse versatility of the plant and their potential against various ailments and diseases. There is a need to conduct further studies to explore exact bioactive molecule isolation and their pharmacokinetics and also to know the effects on structure-function relationship. This study finally concludes that T. Portulacastrum L. is an extraordinary and incredible source with so much to offer the world of medicine.

Acknowledgements Authors sincerely acknowledge Prof. Aditya Shastri, Vice Chancellor, Banasthali Vidyapith, Rajasthan, India, for research facilities and infrastructure.

Author's contribution Purnima Pathak and Sneha Bhatt did literature search and compilation of results. Anand Prakash and Pracheta carried out all experiments as well as compilation of results. Anand Prakash and Vinay Sharma drafted the manuscript.

\section{Compliance with ethical standards}

Conflict of interest All authors declared that they have no conflict of interest in the publication.

Human and animal rights This article does not contain any studies with human participants or animals performed by any of the authors.

\section{References}

1. Acharya R, Jani S, Chinnappa R, Sukla V (2018) Pharmacognostical and phytochemical analysis on Leaves of Homalium ceylanicum (Gardn.) Benth. Pharmacogn J 10:272-277

2. Agashe S, Gopalkrishnan B, Kumavat U, Dixit A (2015) Pharmacognosy and Nutraceutical potential of Trianthema portulacastrum Linn. World J Pharm Res 4:1573-1580

3. Anonymous, World Health Organization (WHO) (1998) Quality control methods for medicinal plant materials. WHO, Geneva

4. Banu GS, Kumar G, Murugesan AG (2009) Ethanolic leaves extract of Trianthema portulacastrum $\mathrm{L}$. ameliorates aflatoxin $\mathrm{B}_{1}$ induced hepatic damage in rats. Ind J Clin Biochem 24:250-256

5. Baravalia Y, Nagani K, Chanda S (2011) Evaluation of pharmacognostic and physicochemical parameters of Woodfordia fruticosa Kurz. Flowers. Phrmacog J 2:13-18

6. Bashir S, Abbas S, Khan A (2018) Pharmacological studies on prokinetic and laxative effects of Trianthema portulacastrum Linn. Int J Complement Alt Med 11:368-373

7. Begum A, Sindhu K, Giri K, Umera F, Gauthami G, Kumar JV, Naveen N, Rao KNV, Ali SS, Sri K, Dutt R (2017) Pharmacognostical and Physio-chemical evaluation of Indian Asparagus officinalis Linn family Limiaceae. Int J Pharmacogn Phytochem Res 9:327-336

8. Bereket T, Tilahu T (2017) Extraction of essential oil from neem seed by using Soxhlet extraction methods. Int J Adv Eng Man Sci 3:646-650

9. Bhushan B, Sardana S, Bansal G (2015) Phytochemical and pharmacognostical studies of leaves of Jasminum mesyni Hance. J Chem Pharm Res 7:922-926

10. Boldosano HY, Castillo BMG, Elloran CDH, Bacani FT (2015) Effect of particle size, solvent and extraction time on tannin extract from Spondias purpurea bark through Soxhlet extraction. Proceeding DLSU Res Cong 3:01-08

11. Chakraborthy GS (2009) Pharmacognostical and phytochemical evaluation of leaf of Abutilon indicum (Linn.). Int J Pharm Sci Drug Res 1:28-31

12. Chase CR, Pratt RJ (1949) Florescence of powdered vegetable drugs with particular reference to development of the system of identification. J Am Pharm Assoc 38:324-331

13. Das K, Tiwari RKS, Shrivastava DK (2010) Techniques for evaluation of medicinal plant products as antimicrobial agent: current methods and future trends. J Med Plant Res 4:104-111

14. Deb NK, Singh A, Rathore DS, Dash GK, Deb J (2015) Pharmacognostic studies of the stem bark of Chloroxylon swietenia DC. Indian J Pharm Biol Res 3:1-5

15. Desai D, Chanda S (2014) Pharmacognostic study and physicochemical analysis of leaves of Terminalia arjuna. Pharmacog $J$ 6:15-19

16. Dhole JA, Dhole NA, Lone KD, Bodke SS (2012) Preliminary Phytochemical analysis of weeds in Marathwada region. Res $J$ Pharm Biol Chem Sci 3:764-767

17. Evans WC (2005) Trease and Evans' Pharmacognosy, 16th edn. Rajkamal Electric press, Delhi, pp 516-536

18. Gaddeyya G, Ratna PK (2015) A comprehensive review on ethnobotany and photochemistry of an herbal weed Trianthema portulacastrum L. J Pharmacog Phytochem 4(4):25-31

19. George VC, Kumar DRN, Suresh PK, Kumar RA (2012) A review on the therapeutic potentials of parthenolide: a sesquiterpene lactone. Int Res J Pharmacy 3:69-73

20. Goswami S, Singhai R (2015) Evaluation of physicochemical parameters of Moringa oleifera leaves. Flora and Fauna 21:169-172 
21. Jain S, Sharma P, Jhade D, Sharma NK, Paliwal P, Ahirwar D (2011) Pharmacognostic screening and phytochemical evaluation of Acacia leucophloea root. Int J Green Pharm 5(2):155-159

22. Janarthanan L, Karthikeyan V, Jaykar B, Balakrishnan BR, Senthilkumar KL, Anandharaj G (2016) Pharmacognostic studies on the whole plants of Ageratum conyzoides Linn. (Asteraceae). Eur J Pharm Med Res 3:618-626

23. Jha SV, Bhagwat AM, Pandita NS (2012) Pharmacognostic and phytochemical studies on the rhizome of Nardostachys jatamansi DC. using different extracts. Phcog J 4:16-22

24. Juna BGR, Sugunan VS, Beevy SS (2017) Nutraceutical evaluation of Boerhavia diffusa L. Int J Curr Pharm Res 9:101-104

25. Kaneria M, Chanda S (2011) Phytochemical and pharmacognostic evaluation of leaves of Psidium guajava L. (Myrtaceae). Pharmacog J 3:41-45

26. Karim S, Kalam MA, Alam A, Alam K, Jahan N, Jafri MA (2015) Biskhapra (Trianthema portulacastrum Linn) and its medicinal utility mentioned in Unani system of medicine-a review. Int J Pharm Sci Res 6:790-795

27. Kasthuri OR, Ramesh B (2018) Physicochemical and fluorescence analysis of leaves of Alternanthera brasiliana (L.) Kuntze and Alternanthera bettzickiana (Regel) Voss. Int J Pharm Sci Rev Res 51:66-71

28. Kavitha R (2014) Fluorescence and FT-IR analysis of leaf and fruit of Trichosanthes dioica ROXB. World J pharm pharmac sci 3:563-572

29. Khandelwal KR (2008) Practical pharmacognosy techniques and experiments. Nirali Prakashan, Pune, pp 149-158

30. Kumar A, Jha KK, Kumar D, Agrawal A, Gupta A (2012) Preliminary Phytochemical Analysis of Leaf and Bark (Mixture) Extract of Ficus Infectoria Plant. The Pharm J 1:71-76

31. Kumar G, Banu GS, Pappa VP, Sundararajan M, Pandian RM (2004) Hepatoprotective activity of Trianthema portulacastrum L. against paracetamol and thioacetamide intoxication in albino rats. J Ethnopharmacol 92:37-40

32. Lapornik B, Prosek M, Wondra AG (2005) Comparison of extracts prepared from plant by-products using different solvents and extraction time. J Food Eng 71:214-222

33. Longanatghan V, Kaniakumari DR, Selvakumar P (2017) A study of the physico-chemical and phytochemical parameters of leaves of Mallotus rhamnifolius. Int J Pharmacog Phytochem Res 9(6):858-863

34. Manallack DT, Prankerd RJ, Yuriev E, Oprea TI, Chalmers DK (2013) The Significance of acid/base properties in drug discovery. Chem Soc Rev 42:485-496

35. Mandal A, Bishayee A (2015) Trianthema protulacastrum Linn. displays anti-Inflammatory responses during chemically induced rat mammary tumorigenesis through Simultaneous and differential regulation of NF- $\mathrm{KB}$ and Nrf2 signaling pathways. Int J Mol Sci 16:2426-2445

36. Marshall EJP, Brown VK, Boatman ND, Lutman PJW, Squire GR, Ward LK (2003) The role of weeds in supporting biological diversity within crop fields. Weed Res 43:77-89

37. Meghashree BM, Shantha TR, Venkateshwarlu G, Bhat S (2017) Comparative pharmacognostical and histochemical studies on Benincasa Hispida (Thunb.) CogN. - fruit and seed. Int J Herb Med 5:17-24

38. Nagani KV, Kevalia J, Chanda SV (2011) Pharmacognostical and phytochemical evaluation of stem of Cissus quadrangularis L. Int J Pharm Sci Res 2:2856-2862

39. Nikhal SB, Dambe PA, Ghongade DB, Goupale DC (2010) Hydroalcoholic extraction of Mangifera indica (leaves) by Soxhletion. Int J Pharm Sci 2(1):30-32
40. Pande J, Kanakiya A, Padalia H, Chandra S (2018) Physicochemical, phytochemical and pharmacognostic evaluation of a halophytic Plant, Trianthema portulacastrum L. Int J Curr Microbiol App Sci 7:1486-1502

41. Pande J, Padalia H, Donga S, Chanda S (2018) Development of quality control parameters for the standardization of Aegle marmelos (Roxb) seed. Int J Pharm Sci Res 9:2387-2394

42. Pande J, Padalia H, Rokad N, Chanda S (2018) Cyperus conglomeratus (Cyperaceae) a halophyte from Gujarat: physicochemical, Phytochemical and Pharmacognostic studies. J Phytopharmacol 7:334-340

43. Pramanick DD (2016) Pharmacognostic studies on the pseudobulb of Coelogyne cristata Lindl. (Orchidaceae)-An epiphytic orchid of ethno-medicinal importance. J Pharmacogn Phytochem 5:120-123

44. Prasad VK, Yadav KN, Patel AN, Navsare VS, Bhilwade SK, Patil MJ (2012) Phytopharmacopoeial specifications of Garcinia indica fruit rinds. J Pharmacogn 31:23-28

45. Prasanth DSNBK, Rao AS, Yejella RP (2017) Pharmacognostic study of Argyreia pilosa Wight \& Arn. Root. J Pharm Health Sci 5:207-216

46. Rakholiya K, Kaneria M, Chandra S (2016) Physicochemical and phytochemical analysis of different parts of Indian Kesar Mango-a unique variety from Saurashtra Region of Gujarat. Pharmacogn J 8:502-506

47. Rokad N, Pande J, Chanda S (2018) Pharmacognostic and phytochemical studies of Ipomoea pes-caprae, an halophyte from Gujarat. J Pharmacogn Phytochem 7:11-18

48. Sampathkumar S, Ramakrishnan N (2011) Pharmacognostic and phytochemical investigation of Naringi crenulata (Roxb.) Nicols. Stem. Anc Sci Life 31:17-21

49. Seow LJ, Beh HK, Sadikun Asmawi MZ (2013) Preliminary phytochemical and physicochemical characterization of Gynura segetum (Lour) Merr (Compositae) Leaf. Trop J Pharm Res 12:777-782

50. Sharma N, Singh S, Singh SK (2017) Pharmacognostical standardization and preliminary phytochemical investigations on Acacia auriculiformis A. Cunn. Ex. Benth stem bark. J Med Plants 5:398-402

51. Sharma S, Bhandari A (2014) Pharmacognostical and Phytochemical analysis of stem part of the traditional herb: Zaleya Govindiya. Asian J Pharm Clin Res 7:32-35

52. Sharma V, Pracheta (2013) Macroscopic studies and preliminary pharmacognostical evaluation of Euphorbia neriifolia L. leaves. Indian J Nat Prod Resour 4:348-357

53. Shivanna $Y$, Koteshwara AR (2009) In-vitro antibacterial effect of selected medicinal plant extracts. J Nat Prod 2:64-69

54. Shukla PK, Misra A, Srivastava S (2018) Comparative pharmacognostical and pharmacological evaluation of two Achyranthes species. Pharmacogn J 10:309-314

55. Sugunan VS, Juna BGR, Beevy SS (2017) Neutracutical evaluation of Boerhavia diffusa L. Int J Curr Pharm Res 9(1):101-104

56. Tang G, Lin X, Lai X, Gong X, Ji S (2018) Pharmacognostic studies of Psychotria rubra (Lour.) Poir. Pharmacogn J 10:249-255

57. Tiwari P, Kumar B, Kaur M, Kaur G, Kaur H (2011) Phytochemical screening and extraction: a review. Int Pharm Sci 1:98-106

58. Upreti K, Semwal A, Upadhyaya K, Masiwal M (2013) Pharmacognostical phytochemical screening of leaf extract of Zanthoxylum armatum DC. Int J Herb Med 1:06-11

59. Vaikosen EN, Alade GO (2011) Evaluation of pharmacognostical parameters and heavy metals in some locally manufactured herbal drugs. J Chem Pharm Res 3:88-97

60. WHO Traditional Medicine Strategy: 2002-2005. Geneva, World Health Organization, 2002. (WHO/EDM/TRM/2002.1) 
61. Yadav RNS, Agarwala M (2011) Phytochemical analysis of some medicinal plants. J Phytol 3:10-14

62. Yaqoob S, Sultana B, Mushtaq M (2014) In-vitro antioxidant activities of Trianthema portulacastrum L. hydrolysates. Prev Nutr Food Sci 19:27-33

63. Yazdinezhad A, Ramezanloo N, Mozaffari S (2016) Pharmacognostic and phytochemical investigation of Heracleum persicum Desf. ex Fischer. Res J Pharmacog 3:17-24
64. Zhao Z, Liang Z, Guo P (2011) Macroscopic identification of Chinese medicinal materials: traditional experiences and modern understanding. J Ethnopharmacol 134:556-564

Publisher's Note Springer Nature remains neutral with regard to jurisdictional claims in published maps and institutional affiliations. 